\title{
Outsourcing Practices: Benefits and Pitfalls as Perceived by Professionals and Managers
}

\author{
Prakash Shrestha, Ph.D. \\ Lecturer, Nepal Commerce Campus, T.U.
}

\begin{abstract}
This study aims to examine the promising benefits and pitfalls of outsourcing practices in the Nepalese industries. This paper follows a descriptive research design. By using a selective sampling technique, a total of 555 questionnaires were distributed to the professionals and managers of 37 companies listed in the Nepal Stock Exchange (NEPSE) in different types of industries of Nepal. Based on the empirical results it is found that concentration on core activities and competencies, improve responsiveness to customers, increased flexibility, quality improvements, cost-saving, and accountability are the top-ranked benefits of outsourcing practices in Nepalese industries. Change problems, contract costs, maintaining the relationship, lost opportunity, and loss of distinctive competencies are some of the notified pitfalls of outsourcing practices. Also, the companies may suffer from the lost opportunity because selling a strategic resource may end up costing them in the long-run. Due to outsourcing practices, the companies may suffer from losing public image, quality of service, outsourcer profit, loss of flexibility, and losing control as well. Therefore, the companies should be serious regarding outsourcing decision-making. To get more benefits from these practices companies need to maintain a smooth relationship with suppliers and vendors. They need to select the partners who match to expertise and business scale. They also need to consider the costs and risks associated with such practices. They need to focus on effective communications in terms of cost, time differences, and cultural difficulties and protect intellectual property as well. At the top of all the companies also need to consider customers' attitudes, expectations, and needs.
\end{abstract}

Keywords: Outsourcing, Benefits, Pitfalls, Business activities, Industries, Professionals, Managers.

\section{Introduction}

In the business world, outsourcing is becoming popular. Managers are looking for any advantage that can provide them with success in today's environment. Another strategy that can contribute to greater competitiveness is outsourcing (Weston, 1996). Outsourcing chooses to purchase selected products and services from outside a company. It is a way to identify new suppliers and new ways to ensure the supply of raw materials, products, components, and services through the use of new suppliers' expertise, experience, and innovation not previously used (Kraker, 1995). Outsourcing requires a long-term supplier-beneficiary relationship with a high degree of risk-sharing (cited in Embleton \& Wright, 1998). Zhu, Hsu, and Lilie (2001) state that outsourcing is the process of shifting responsibility from an employee group to a nonemployee group for a particular business purpose. It is a business concept that looks for expertise to handle certain business functions outside the existing firm. 
The increased emphasis on outsourcing is a natural progression of today's competitive world. The emphasis of outsourcing is on cost savings and increased profit in an economic climate (Embleton \& Wright, 1998). It involves transferring ownership of an organization's business activities to an outside provider (Juras, 2007). Cost reduction is one of the key objectives of outsourcing practice. After cost reduction, however, many previous studies (e.g. Raynor, 1992; Gibson, 1996; Knowles, 1996; Collins \& Millen, 1995; Lacity \& Willcocks, 1998; Quinn \& Hilmer, 1994; Behara, Funderson, \& Capozzoli, 1995; Strassmann, 1997; McFarlan \& Nolan, 1995, Sturm, Morris, \& Jander, 2000; Davey and Allgood, 2002; Lacity \& Willcocks, 2001; Lonsdale \& Cox, 2000; Useem \& Harder, 2000; Caldwell \& McGee, 1996; Embleton \& Wright, 1998; Zhu, Hsu, and Lilie, 2001; Linder, Cole and Jacobson, 2002; Franceschini et al., 2003; Juras, 2007; Tayauova, 2012; Hayler, 2015; Rao, 2016; Aswini, 2018) reported the many reasons behind the companies to decide to outsource such as to leverage technical expertise, access to labor expertise, improved customer value, to gain competitive advantage, consolidation of assets/resources, increased shareholder value, lack of in-house resources, and increased flexibility (Hayler, 2015).

Outsourcing creates and adds value to the business by enabling the executives to concentrate on strategic areas, improving processes and saving money, and increasing business capabilities. It has been increasing to meet the growing international demand for lucrative and customer-interaction centers (Rao, 2016). Although many areas and functions are outsourced, here are some of the frequently outsourced areas information technology, legal services, content development, web design, network and communication, human resources and insurance administration, logistics, manufacturing, technology/customer supports, account, marketing, security, and like. Outsourcing is a popular option for business organizations in this intensely competitive age. To achieve competitiveness in the business sector, the concept of outsourcing is getting popular in the Nepalese context too. Thus, this study aims to examine the promising benefits and pitfalls of outsourcing practices in the Nepalese industries.

\section{Literature Review}

The practice of outsourcing has become an increasingly popular method of cost reduction in the business sector. Outsourcing is the process of sub-contracting services and operations to other firms that can do them cheaper or better or both. Many previous sources of literature have shed light on outsourcing practices at businesses. Ehie (2001) claims that companies that adopt a strategic outlook on outsourcing have a better success rate than those that embark on outsourcing as a short-term cost-cutting decision. Outsourcing should be seen as a method to enable the firm to focus on its core competencies. Competitive and market factors such as increasing manufacturing flexibility, reducing inventory investments, ability to respond quickly to changing market requirements are being recognized as some of the real importance of outsourcing. Linder, Cole, and Jacobson (2002) also mention that outsourcing is a program to change the way a company works to achieve a rapid, sustainable, radical improvement in enterprise-level performance. Franceschini et al. (2003) observed that cost efficiency and production reorganization are the two most significant factors for outsourcing. Companies may concentrate their efforts by outsourcing on core sector, medium-/long-term objectives, and opportunities for diversification.

Regarding benefits and pitfalls of outsourcing practices, many previous studies (e.g., Kraker, 1995; Beaumont \& Costa, 2002, 2003; Neale, 1995; Cassidy, 1994; Raynor, 1992; Gibson, 1996; Knowles, 1996; Collins \& Millen, 1995; Lacity \& Willcocks, 1998; Quinn \& Hilmer, 1994; Behara et al., 1995; Strassmann, 1997; McFarlan \& Nolan, 1995, Sturm et al., 2000; Davey and Allgood, 2002; Lacity \& Willcocks, 2001; Lonsdale \& Cox, 2000; Useem \& Harder, 2000; Caldwell \& McGee, 1996; Embleton \& Wright, 1998; Zhu, Hsu, and Lilie, 2001; Linder, Cole and Jacobson, 2002; Franceschini et al., 2003; Juras, 2007; Tayauova, 2012; Hayler, 2015; Rao, 2016; Aswini, 2018) have presented their results. Based on the results of these studies, cost-saving, time-saving, concentration on core activities and competencies, avoidance of cultural problems, cash infusion, increased flexibility, accountability, employment peace, handling geographical difficulties; distraction, and quality improvements are considered as the potential 
benefits of outsourcing. Besides, some of the benefits of outsources are access to technology, access to expertise, improve responsiveness to customers, improved productivity, increased capacity, reduction capital expenditure, and reconfiguration. Moreover, some other benefits of outsourcing are financial gains, strategic enhancements, shortened cycle time, reduced employee training cost, improved management system, increased innovations, decreased business risks and provided formidable barriers to make an entry. However, there are some possible pitfalls of outsourcing practice. Some of them are maintaining the relationship, loss of distinctive competencies, change problems, loss of flexibility, contract costs, quality of service, control, lost opportunity, public image, and outsourcer profit.

\section{Research Methodology}

This paper follows a descriptive research design. The questionnaire survey is a basic research method applied to collect data regarding the possible benefits and pitfalls of outsourcing practices in businesses. By using a selective sampling technique, a total of 555 questionnaires were distributed to the professionals and managers of 37 companies listed in the Nepal Stock Exchange (NEPSE) in different types of industries of Nepal. The perception of these professionals and managers was measured based on a 5-point Likert scale where 1 indicates no benefits and 5 indicates the most benefit of outsourcing practices. The detail of industries and response rate is depicted in the following table.

Table 1

Industries Surveyed and Response rate

\begin{tabular}{lcccc}
\hline Industries & $\begin{array}{c}\text { No. of } \\
\text { Companies }\end{array}$ & $\begin{array}{c}\text { Distributed } \\
\text { Questionnaires }\end{array}$ & $\begin{array}{c}\text { Received } \\
\text { Questionnaires }\end{array}$ & $\begin{array}{c}\text { Response } \\
(\%)\end{array}$ \\
\hline Commercial Banks & 5 & 75 & 56 & 74.67 \\
Development Banks & 5 & 75 & 62 & 82.67 \\
Finance Companies & 5 & 75 & 68 & 90.67 \\
Life Insurance Companies & 5 & 75 & 70 & 93.33 \\
Non-Life Insurance Companies & 5 & 75 & 68 & 90.67 \\
Hydropower Companies & 5 & 75 & 61 & 81.33 \\
Manufacturing and Processing & 5 & 75 & 53 & 70.67 \\
Companies & 2 & 30 & 23 & 76.67 \\
Hotels & 37 & 555 & 461 & 83.06 \\
Total & & &
\end{tabular}

\section{Data Analysis, Results, and Findings}

\section{Possible Benefits of Outsourcing Practices}

Table 2 presents the variables under the possible benefits of adopting outsourcing practices in business activities.

Table 2

Possible Benefits of Outsourcing

\begin{tabular}{llcc}
\hline S.N. & Indicators & Mean & Rank \\
\hline 1. & Cost-saving & 4.15 & 5 \\
2. & Time-saving & 4.04 & 7 \\
3. & Concentration on Core Activities and Competencies & 4.55 & 1 \\
4. & Avoidance of Cultural Problems & 3.87 & 13 \\
5. & Cash Infusion & 4.01 & 9 \\
\hline
\end{tabular}




\begin{tabular}{llcc}
\hline 6. & Increased Flexibility & 4.45 & 3 \\
7. & Employment Peace & 4.02 & 8 \\
8. & Accountability & 4.05 & 6 \\
9. & Handling Geographical Difficulties & 3.95 & 11 \\
10. & Distraction & 3.99 & 10 \\
11. & Quality Improvements & 4.31 & 4 \\
12. & Access to Technology & 3.82 & 14 \\
13. & Improve Responsiveness to Customers & 4.51 & 2 \\
14. & Improved Productivity & 3.89 & 12 \\
15. & Improved Management Systems & 3.41 & 15 \\
\hline
\end{tabular}

Table 2 presents the key possible benefits of outsourcing practices. The results indicate that the top six biggest benefits from outsourcing are the concentration on core activities and competencies, improve responsiveness to customers, increased flexibility, quality improvements, cost-saving, and accountability. Besides, professionals and managers also believe that outsourcing provides some benefits such as timesaving, employment peace, cash infusion, distraction, handling geographical difficulties, improved productivity, avoidance of cultural problems, and access to technology. Finally, they rank improved management systems as the least benefit of outsourcing.

\section{Possible Pitfalls of Outsourcing Practices}

Table 3 presents the variables under the possible pitfalls of adapting outsourcing practices in business activities.

Table 3

Possible Benefits of Outsourcing

\begin{tabular}{llll}
\hline S.N. & Indicators & Mean & Rank \\
\hline 1. & Maintaining the Relationship & 4.26 & 3 \\
2. & Quality of Service & 4.02 & 7 \\
3. & Change Problems & 4.47 & 1 \\
4. & Loss of Flexibility & 3.99 & 9 \\
5. & Outsourcer Profit & 4.01 & 8 \\
6. & Loss of Distinctive Competencies & 4.15 & 5 \\
7. & Control & 3.85 & 10 \\
8. & Lost Opportunity & 4.22 & 4 \\
9. & Public Image & 4.14 & 6 \\
10. & Contract Costs & 4.35 & 2 \\
\hline
\end{tabular}

Table 3 presents the key possible pitfalls of outsourcing practices. The results indicate that the top five biggest pitfalls or problems from outsourcing are change problems, contract costs, maintaining the relationship, lost opportunity, and loss of distinctive competencies. Besides, professionals and managers also believe that outsourcing provides some problems in terms of public image, quality of service, outsourcer profit, and loss of flexibility. Finally, they rank control as the least pitfall of outsourcing practice.

\section{Discussion and Conclusion}

It is found, based on the empirical results that concentration on core activities and competencies, improve responsiveness to customers, increased flexibility, quality improvements, cost-saving, and accountability are the top-ranked benefits of outsourcing practices in Nepalese industries. These findings 
are consistent with the results of Embleton and Wright (1998), Aswini (2018), Collins and Millen (1995), Lacity and Willcocks (1998), Quinn and Hilmer (1994), Behara et al. (1995), Strassmann (1997), McFarlan and Nolan (1995), Ehie (2001), Jiang and Qureshi (2006), and Canez et al (2002), who reported that priorities for outsourcing help to achieve supply reliability, speed of response, price competitiveness, and high-quality and high-performance items. Outsourcing helps to meet these targets, in addition to freeing up capital for investment in core competencies. Most of these studies concluded that companies need to outsource activities in which they are less competent and can benefit from vendors' expertise. Due to outsourcing practices, companies can improve their responsiveness to customers with fast and quality goods and services. With the help of outsourcing, they also can improve workflow flexibility and save the cost significantly. The companies also can enhance the accountability of vendors by contract to provide agreed levels of service. To some extent, with the practice of outsourcing companies also can benefit from time-saving, employment peace, cash infusion, distraction, handling geographical difficulties, improved productivity, avoidance of cultural problems, and access to technology and improved management system.

However, the paper noticed some of the pitfalls of outsourcing practices. Change problems, contract costs, maintaining the relationship, lost opportunity, and loss of distinctive competencies are some of the notified pitfalls of outsourcing practices. It is believed that the practices of outsourcing companies may in the problem of maintaining a relationship with many vendors. Maintaining such a relationship can be a lengthy and expensive exercise for the companies as reported by Sturm et al. (2000). Also, the companies may suffer from the lost opportunity because selling a strategic resource may end up costing them in the long-run. In some cases, the companies may lose distinctive competencies because the vendors may enhance the capacity of competitors. Likewise, due to outsourcing practices, the companies may suffer from losing public image, quality of service, outsourcer profit, loss of flexibility, and losing control as well. Therefore, the companies should be serious regarding outsourcing decision-making.

\section{Practical Implications}

Today, companies need not produce goods and services themselves. With the increasing trend of globalization, outsourcing practices have become one of the best ways that offer companies to focus on what they do best what other companies can do different, smoother, cheaper, and nicer. Even though there are many benefits of such practices, companies should not neglect the pitfalls associated with outsourcing practices of business activities. To get more benefits from these practices companies need to maintain a smooth relationship with suppliers and vendors. They need to select the partners who match to expertise and business scale. They also need to consider the costs and risks associated with such practices. They need to focus on effective communications in terms of cost, time differences, and cultural difficulties and protect intellectual property as well. At the top of all the companies also need to consider customers' attitudes, expectations, and needs.

\section{References}

Aswini, K. (2018). Advantages and disadvantages of outsourcing. Shanlax International Journal of Commerce, 6(1), 7-9.

Behara, R.S., Funderson, D.E., \& Capozzoli, E.A. (1995). Trends in information systems outsourcing. International Journal of Purchasing and Materials Management, 31(2), 45-51.

Caldwell, B., \& McGee, M.K. (1996). DuPont goes outside. Informationweek, 610, 14-16.

Canez, L.E., Platts, K.W., \& Probert, D.R. (2000) Developing a framework for make-or-buy decisions. International Journal of Operations and Production Management, 20(11), 1313-1330.

Collins, J.S., \& Millen, R.A. (1995). Information systems outsourcing by large American industrial firms: choices and impacts. Information Resources Management Journal, 8(1), 5-13.

Davey, H., \& Allgood, B. (2002). Offshore development, building relationships across international boundaries: a case study. Information Strategy: The Executive's Journal, Spring, 13-16. 
Ehie, I.C. (2001). Determinants of success in manufacturing outsourcing decisions: A survey study. Production and Inventory Management Journal, 42(1), 31-39.

Embleton, P.R., \& Wright, P.C. (1998). A practical guide to successful outsourcing. Empowerment in Organizations, 6(3), 94-106.

Franceschini, F., Galetto, M., Pignatelli, A., \& Varetto, M. (2003). Outsourcing: Guidelines for a structured approach. Benchmarking: An International Journal, 10(3), 246-260.

Gibson, V.M. (1996). Outsourcing can save money and increase efficiency. Benefits Administration, March, p. 19.

Hayler, D. (2015). Exploring outsourcing as a source of competitive advantage. Kinston University, London, England.

Jiang, B., \& Qureshi, A. (2006). Research on outsourcing results: current literature and future opportunities. Management Decision, 44(1), 44-55.

Juras, P. (2007). A risk-based approach to identifying the total cost of outsourcing. Management Accounting Quarterly, 9(1), 43-50.

Knowles, L. (1996). Outsourcing. Canadian Business, 69(6). 87-92.

Kraker, F. (1995). The Truth about Outsourcing. Brian Roherty and Ian Robertson, Gower, Aldershot and Brookfield, VT.

Lacity M.C., \& Willcocks, L.P. (1998). An empirical investigation of information technology sourcing practices: lessons from experience. MIS Quarterly, 22(3), 363-408.

Lacity, M.C., \& Willcocks, L.P. (2001). Global Information Technology Outsourcing: in Search of Business Advantage. Wiley, Chichester and New York, NY.

Linder, J.C., Cole, M.I., \& Jacobson, A.L. (2002). Business transformation through outsourcing. Strategy and Leadership 30(4), 23-28.

Lonsdale, C., \& Cox, A. (2000). The historical development of outsourcing: the latest fad? Industrial Management and Data Systems, 100(9), 444-450.

McFarlan, F.W., \& Nolan, R.L. (1995). How to manage an IT outsourcing alliance. Sloan Management Review, 36(2), 9-22.

Quinn, J.B., \& Hilmer, F.G. (1994). Strategic outsourcing. Sloan Management Review, 35(4), 43-55.

Rao, P. S. (2016). Business Policy and Strategic Management: Text and Cases. Mumbai: Himalaya Publishing House, p. 141.

Raynor, M.E. (1992). The outsourcing solution. Canadian Business Review, 19, 42-44.

Strassmann, P.A. (1997). The squandered computer: evaluating the business alignment of information technologies. Information Economics, New Canaan, CT.

Sturm, R., Morris, W., \& Jander, M. (2000). Foundations of Service Level Management. SAMS, Indianpolis.

Tayauova, G. (2012). Advantages and disadvantages of outsourcing: analysis of outsourcing practices of Kazakhstan banks. Procedia - Social and Behavioral Sciences, 41, 188 - 195.

Useem, M., \& Harder, J. (2000). Leading laterally in company outsourcing. Sloan Management Review, 41(2), 25-36.

Weston, R. (1996). It's hard to buck the outsourcing tide. PC Week, 15 July.

Zhu, Z., Hsu, K., \& Lilie, J. (2001). Outsourcing-a strategic move: The process and the ingredients for success. Management Decision, 39(5), 373-378. 